\title{
Characteristics and Controlling Factors of the Chang 8 Oil Reservoir in the Yanchi Area of the Ordos Basin: A Case Study of Well G20
}

\author{
Xiaozhou Shao $\mathbb{D}^{1},{ }^{1,2,3}$ Yong Li, ${ }^{1}$ Miaomiao Wang $\mathbb{D}^{4},{ }^{4}$ Meijuan $\mathrm{Chu},{ }^{2,3}$ Yalin Qi, ${ }^{2,3}$ \\ and Xiaolei Zhang ${ }^{2,3}$ \\ ${ }^{1}$ College of Energy Resources, Chengdu University of Technology, Chengdu, Sichuan 610059, China \\ ${ }^{2}$ National Engineering Laboratory for Exploration and Development of Low-Permeability Oil \& Gas Fields, Xi'an, \\ Shaanxi 710018, China \\ ${ }^{3}$ Research Institute of Exploration and Development, PetroChina Changqing Oilfield Company, Xi'an, Shaanxi 710018, China \\ ${ }^{4}$ School of Highway, Chang'an University, Xi'an 710064, China
}

Correspondence should be addressed to Miaomiao Wang; wmmcugb@163.com

Received 1 September 2021; Revised 25 December 2021; Accepted 19 January 2022; Published 22 February 2022

Academic Editor: Henrik Drake

Copyright $\odot 2022$ Xiaozhou Shao et al. This is an open access article distributed under the Creative Commons Attribution License, which permits unrestricted use, distribution, and reproduction in any medium, provided the original work is properly cited.

In the Ordos Basin, the Chang 8 oil reservoir of the Triassic Yanchang Formation is the main target of oil exploration and development and there are many factors affecting the hydrocarbon accumulation. Well G20 is an important exploration well in the Yanchi area in the northwestern part of the basin, and the core of the Chang 8 reservoir was sampled and tested to determine the source rocks, trace element composition, mineral composition, reservoir physical properties, and oil-bearing properties. The results show that the rock retrieved exhibits delta plain subfacies; the range of the Chang 8 water body was large, with a gentle slope, and the climate was relatively dry. These findings suggest that this reservoir was deposited in an environment in which sedimentary sand body could easily form. The Chang 8 sandstone reservoir pores are dominated by intergranular pores and feldspar intragranular dissolution pores, indicating that the Chang 8 reservoir is a low-porosity and low-permeability reservoir. Chang 7 source rocks from this area have a type I-II1 hydrocarbon-generating potential, with an average total organic carbon (TOC) content of $5.99 \%$ and vitrinite reflectance (Ro) value of $0.48 \%$. Combined with the regional sedimentary evolution, tectonic movement, and reservoir distribution, it is considered that due to the lack of lithologic traps or low-amplitude structural traps, G20 produced water in well testing. The Chang 8 oil reservoir in the Yanchi area can be divided into structural reservoirs and structural-lithologic reservoirs. The conventional oil and gas reservoir exploration ideas of "thick sand belt" and "reservoir sweet spot" are not applicable here. The lithology traps or low-amplitude structural traps and areas with good preservation conditions are the main directions for the next phase of exploration in the northwestern part of the Ordos Basin.

\section{Introduction}

The Ordos Basin is the second-largest sedimentary basin in China. The Triassic Yanchang Formation in the Ordos Basin is mainly composed of a set of inland clastic sedimentary layers with thicknesses of 500-1200 m. The Yanchang Formation can be divided into 10 oil-bearing members (Chang 10 to Chang 1, from the bottom to the top) and is the main oil-producing layer in the basin. The Chang 7 oil-bearing member is mainly composed of a set of gray-black mudstones with a high organic carbon content and an organic matter type that is favorable for oil generation. Mudstone is an important source rock in the basin and the adjacent Chang 8 member is the main oil-bearing layer. At present, several oil fields containing millions of tons of oil have been found, such as Jiyuan and Huanjiang field [1-3]. With the continuous discovery of oil resources in the basin, oil and gas exploration has gradually shifted from a large area of oil-bearing lithologic oil and gas reservoirs in the basin to complex structural-lithologic oil and gas reservoirs around the basin $[4,5]$. 
Many research studies about the sedimentation, reservoir, and hydrocarbon accumulation characteristics of Yanchang Formation have been conducted in the basin. Ren et al. [6] considered that the sedimentary microfacies and high-quality reservoirs control the formation and enrichment of low-permeability oil layer in the Yanchang Formation. The hydrocarbon-generation intensity of source rocks directly controls the lateral distribution of oil in the Chang 8 member. Shen et al. [7] found that the sweet spot and near-source accumulation are the main conditions for tight oil accumulation. Luo et al. [8] and Chu et al. [9] suggested that the oil and gas generated in Chang 7 is driven into the overlying Chang 6 and Chang $4+5$ members and the underlying Chang 8 member by two-way hydrocarbon expulsion through overpressure. Chen et al. [10] and Xia et al. [11] considered that the argillaceous interlayer between a source and reservoirs hinders the migration of crude oil, and the later fault activity connects and changes the previously formed reservoirs. All these results agree with the oil exploration theories of "source control" and "high quality reservoir" $[12,13]$, which means that the main controlling factors of oil reservoir are "thick sand belt" and "reservoir sweet spot (the part of the reservoir with higher porosity and permeability).”

Well G20, located in the northwest Ordos Basin, is a key preexploration well with the farthest deployment. The purpose of drilling was to reveal the regional oil exploration potential. A certain thickness of source rock is distributed in the area, and it is much easier for hydrocarbon to accumulate in "thick sand belt" and "reservoir sweet spot." However, G20 well produced unexpected water in testing. Therefore, the main controlling factors of oil reservoir in this area are not clear and need further investigation.

In this study, the sedimentation, hydrocarbon-generation, reservoir-forming, and oil-bearing characteristics of the Chang 8 member of the G20 well are analyzed. Combined with the regional sedimentary evolution, tectonic movement, and reservoir distribution in the Yanchi area, this study sets out to explain the causes of the unexpected water production in well G20. A potentially favorable exploration direction of the Chang 8 reservoir in the Yanchi area is also discussed, which provides a theoretical basis for identifying reserve replacement resources.

\section{Geological Background}

The Ordos Basin is a composite basin of a Mesozoic Cenozoic basin superimposed on a Paleozoic basin. Its present structural characteristics include an asymmetric rectangular basin with a wide and gentle east slope and a steep and narrow west slope. According to the present structural form, the Ordos Basin can be divided into six first-order structural units (Figure 1): Yimeng uplift, Weibei uplift, Western Shanxi flexure fold belt, Yishan slope, Tianhuan syncline, and western margin thrust fault structural belt [14-16]. The Yanchang Formation can be divided into 10 oil-bearing members with conforming sedimentary contacts between them. Among them, the Chang 10 to Chang 7 sedimentary period is the formation period of the lake basin; the Chang 6 to Chang 3 period is the development period of the lake basin and is dominated by delta construction; and the Chang 2 to Chang 1 sedimentary period corresponds to the lake basin gradually shrinking, eventually ending the sedimentation process of the Yanchang Formation. Among them, Chang 8 is the main hydrocarbon-bearing strata in the basin, and Chang 7 is the most important source rock [17].

\section{Sample and Analytical Method}

Taking well G20 as an example, the study focuses on the observation of the sedimentary structure phenomenon of Chang 8 , and the total length of the core is $38.1 \mathrm{~m}$. To determine the rock type, reservoir physical properties, and oilbearing properties, 255 core samples were collected. Among them, 187 samples were analyzed for porosity, permeability, and detrital composition; 11 samples were analyzed by fluorescence and nuclear magnetic resonance; 13 samples were analyzed by scanning electron microscopy; 15 samples were analyzed by cathodoluminescence; and 3 oil sand samples were analyzed by saturated hydrocarbon mass spectrometry.

TOC analysis was performed with a LECO CS744 carbon-sulfur analyzer. One gram of sample was added to a crucible, the inorganic carbon was removed with dilute hydrochloric acid, and the sample was then rinsed with distilled water; the sample was then dried in an oven at $100^{\circ} \mathrm{C}$ for $12 \mathrm{~h}$ to perform TOC measurements. Hydrocarbon generation analysis was carried out using a ROCK-Eval6 apparatus. The rock sample was crushed until the particle size was less than $0.2 \mathrm{~mm}$, and each sample was at least $1 \mathrm{~g}$. With nitrogen as the carrier gas, a sample was heated from $300^{\circ} \mathrm{C}$ to $600^{\circ} \mathrm{C}$ without oxygen, and parameters such as the adsorbed hydrocarbon $\left(S_{1}\right)$ and pyrolytic hydrocarbon $\left(S_{2}\right)$ were detected. Gas chromatography-mass spectrometry (GC-MS) analysis was carried out using Thermo-Fisher Trace-DSQ II, which can detect the combination characteristics of biomarkers in crude oil, saturated hydrocarbon, aromatic hydrocarbon, and other components. The temperature of the injection port was $300^{\circ} \mathrm{C}$, and the carrier gas was helium. The carrier gas flow rate was $1 \mathrm{ml} / \mathrm{min}$, and the ionization energy was $70 \mathrm{eV}$ [18].

The rock type and composition of the sample were determined by polarizing microscopy with a LEICA 4500P apparatus. The analysis of oil saturation and movable fluid saturation volume was completed by a DRX MARAN-2 nuclear magnetic resonance analyzer. Fluorescence analysis and Ro were completed by a MPV-SP microspectrophotometer. Field emission-scanning electron microscopy was performed with an electronic microscope (model Quanta450FEG, produced by FEI) with a high resolution, which can be used for both imaging secondary electrons and image processing of the surface morphology of various solid samples [19]. As seen in the images of secondary electrons, this instrument can observe samples with or without a coating at low voltage to obtain the original morphology and ultrastructural information of a sample surface.

In this study, all the core sample collection and observation work was carried out in the CNPC Changqing Oilfield 


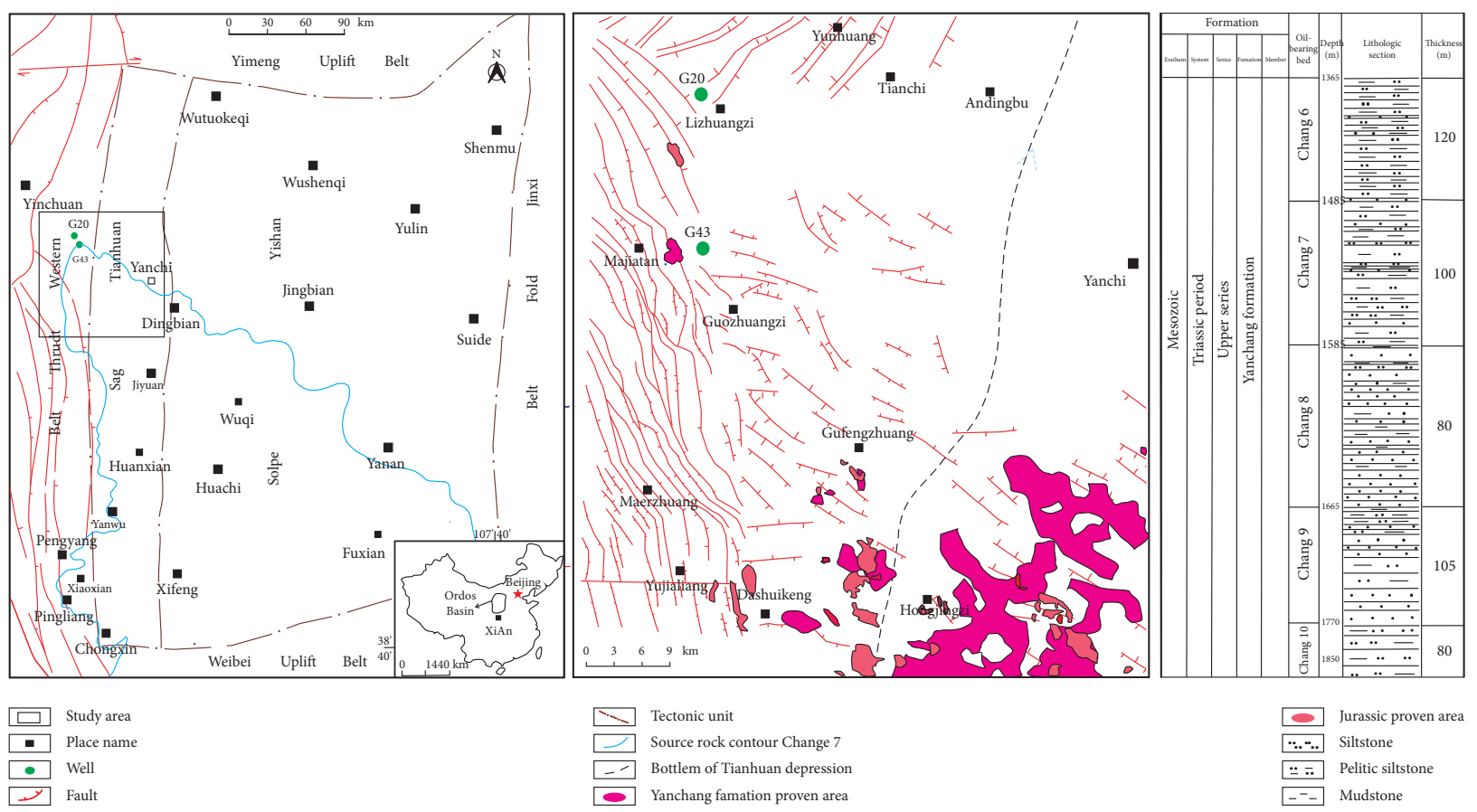

Figure 1: Structural division and stratigraphic distribution in the northwest Ordos Basin.

Company, and the testing work was completed in the $\mathrm{Na}$ tional Engineering Laboratory for Exploration and Development of Low-Permeability Oil \& Gas Fields. The testing process and data analysis were performed in accordance with the national standards of China and the relevant standards of the oil and gas industry.

\section{Results}

4.1. Sedimentary Characteristics. The five signs used to judge the sedimentary environment of well G20 are as follows: (1) the primary color characteristics of the sediments, which can indicate the sedimentary environment; (2) the changes in the vertical grain size and sedimentary structure; (3) the presence of plant stalks, which can indicate the underwater environment near the lake shoreline; (4) the presence of coal seams, which can indicate the onshore sedimentary environment; and (5) the characteristics of the logging facies [20].

The Chang 8 coring section (1650.1-1688.2 m) of well G20 is mainly composed of grayish-white thick-bedded fine siltstone, with a small amount of argillaceous siltstone and silty mudstone, and local deposits of argillaceous lamina and banded oil. This section is mainly composed of distributary channel and distributary bay deposits. The erosion surface at the bottom of the sand body is common, and the upward transition shows thin interbedding of siltstone or silty fine sandstone, siltstone, and argillaceous siltstone. The grain size fines upward. The primary colors of the interbedded mudstone are light gray to black, indicating that the formation and oxidation-reduction interface were above the surface of water. Massive bedding, parallel bedding, and wedge-shaped cross-bedding reflect a high-energy environment; horizontal bedding reflects a still water environment; and wavy cross-bedding reflects weak underwater hydrodynamic conditions. There are few fossils in the sandstone, and only a few carbonized plant fragments distributed along the bedding plane were found. The electrical logging curve of a single underwater distributary channel is bell-shaped, and that of a superimposed underwater distributary channel sand body can be box-shaped, bell-shaped, composite bell-shaped, etc.; the bottom often has an abrupt contact, while the top often has a gradual contact [21]. Here, the spontaneous potential (SP) curve is not straight, but has a box shape or an approximately bell shape, with a high amplitude, while the gamma ray (GR) curve has a low amplitude and little changes, and in the longitudinal section, it is high in the bottom portion and low in the upper portion. Based on the above analysis of the lithology, sedimentary structure, and paleontological indicators and combined with regional geological background data, well G20 at the Chang 8 member is assumed to be the product of sedimentary environment with high water energy resulting in delta plain subfacies.

According to the results of earlier researchers [11], in this area, the bottom scour structure is common in the Chang 8 oil-bearing member of this area. The scour structure is often developed between the overlying coarse-grained sediment and the underlying fine-grained sediment. It is mainly manifested as a straight or undulating lithologic mutation surface, representing a small-scale erosion discontinuity, which is very common in river environments under strong hydrodynamic conditions. In addition, paleontological genetic indicators are relatively developed, and thin coal lines are widely developed, reflecting the sedimentary environment of a delta plain swamp; carbonized reed and plant root 
trace fossils are often found in dark mudstone sections, and biological boreholes and disturbed structures are common in the thin interbedded mudstone and fine-grained sandstone, which are of great significance for identifying the sedimentary environment, lakeshore location, and migration direction. The dark mudstones, which are rich in carbonized plant fossils in swampy lakeshore environments, are cross-bedded vertically with waves, indicating an underwater environment with a large-scale reciprocating oscillation of lake shoreline caused by the high-frequency rise and fall of lake levels during the Chang 8 sedimentary period; these are the characteristics of a shallow lake (Figure 2).

4.2. Paleobathymetric Characteristics. In the process of sedimentation, there is a complex geochemical balance between the sediment and the water. By studying the content and distribution of trace elements in sedimentary rocks, especially the ratios of some related elements, we can infer the sedimentary environment at that time and invert the geological conditions of the sedimentary period [22, 23].

The paleodepth can be determined based on a comprehensive analysis of sedimentary facies and paleontological data, but the results are qualitative or semiquantitative. At present, one of the main methods for the quantitative calculation of paleodepth is to infer the change in the paleosedimentary rate by using the change in the cobalt content [24]. The calculation formula is as follows:

$$
\begin{aligned}
& V_{s}=\frac{V_{O} \times N_{\mathrm{Co}}}{\left(S_{\mathrm{Co}}-t \times T_{\mathrm{Co}}\right)}, \\
& H=\frac{3.05 \times 10^{5}}{\left(V_{S}^{1.5}\right)},
\end{aligned}
$$

where $V_{s}$ represents the deposition rate of a sample; $V_{O}$ represents the normal water deposition rate $(0.15-0.3 \mathrm{~mm} / \mathrm{a})$, the value of which was $0.29 \mathrm{~mm} / \mathrm{a}$ in this study; $N_{\mathrm{Co}}$ represents the abundance of $\mathrm{C}_{\mathrm{O}}$ in normal ocean sediment $(20 \mu \mathrm{g} / \mathrm{g}) ; S_{\mathrm{Co}}$ represents the abundance of $\mathrm{C}_{\mathrm{O}}$ in a sample; $t$ represents the $\mathrm{La}$ content in the sample/the average La abundance in terrigenous detritus ( $\mathrm{La} / 38.99)$; and $T_{\mathrm{Co}}$ represents the Co abundance in terrigenous detritus $(4.68 \mu \mathrm{g} / \mathrm{g})$.

The results are listed in Table 1 . The results show that the depth of the paleolake water in Chang 8 in the Yanchi area is $10-50 \mathrm{~m}$; the average depth is $35 \mathrm{~m}$, and the maximum depth is $51.4 \mathrm{~m}$. The overall water body is large, and the slope is gentle. Wide, moderate, and shallow water bodies are favorable for the development of sand bodies in a delta plain front distributary channel.

4.3. Paleoclimatic Conditions. A dry climate indicates a low $\mathrm{Sr}$ content. Because the $\mathrm{Sr} / \mathrm{Ba}$ ratio increases with the distance from the lake coast, it can qualitatively reflect the paleosalinity of the medium. Generally, a $\mathrm{Sr} / \mathrm{Ba}$ ratio greater than 1.0 indicates a saline water environment, and a ratio less than 1.0 indicates a freshwater environment $(1.0-0.5$ is a medium brackish water phase and less than 0.5 is a little brackish water phase) [25]. Based on the study of the $\mathrm{Sr} / \mathrm{Ba}$ ratios of Chang 8 mudstone samples, the $\mathrm{Sr} / \mathrm{Ba}$ ratios were found to vary from 0.30 to 2.97 , with an average of 1.04 (Figure 3), indicating that the lake water was brackish during the deposition period of the Chang 8 member. This shows that the climate was relatively dry, the evaporation exceeded the rainfall, and the lake water supply mainly relied on seasonal flooding. These climatic conditions were not conducive to the formation and development of large-scale deep-water lakes. The brackish water environment had a limited influence on the development of underwater distributary channels and the long-distance extension to the lake basin, which easily led to the large-scale distribution of sedimentary sand bodies.

4.4. Characteristics of Source Rocks. Well G43 is located near well G20, where a certain scale of shale was found in the Chang 7 member. Through the analysis of 26 mudstone samples from the well, the content of organic carbon was determined to be $1.89 \%-12.33 \%$, with an average of $5.99 \%$, accounting for $31.5 \%$ of the total; $S_{1}+S_{2}$ is $3.64-52.76 \mathrm{mg} / \mathrm{g}$, with an average of $31.74 \mathrm{mg} / \mathrm{g}$. In well G43, dark mudstone rich in organic matter is developed, and the organic matter abundance varies widely. At the same time, the relationship between the TOC content and $S_{1}+S_{2}$ and the relationship between the TOC content and hydrogen index (HI) of the Chang 7 source rock are very strong and have a positive correlation in this area (Figure 4).

According to the kerogen type index results of the source rock, the organic matter type of the Chang 7 source rock is the I-II1 humic sapropel type. The organic macerals are mainly amorphous sapropel that is rich in exinite components, which indicates that the hydrocarbon-generating parent materials are mainly low aquatic organisms mixed with some higher plants, reflecting a weak reduction-weak oxidation environment $[26,27]$. The shale Ro is $0.41 \%-0.57 \%$, with an average value of $0.48 \%$, reflecting that the shale Chang 7 shale is in the low-maturity stage.

The well is close to the Jiyuan area, in which the Chang 7 source rock enters the threshold depth of oil generation at $1700 \mathrm{~m}$. The main oil generation stage is $1700-2800 \mathrm{~m}$, and the high maturity stage is below $2800 \mathrm{~m}$. The burial depth of Chang 8 at G43 is approximately $1680 \mathrm{~m}$, which is in the low-maturity stage. As the burial depth increases, the Ro of the source rocks generally shows an increasing trend, which is closely related to the uplift and erosion intensity of the strata. The Chang 7 mudstone of well G43 has a high abundance of a favorable type of organic matter for hydrocarbon generation, which indicates a set of good source rocks that can provide a certain oil and gas supply for the oil and gas reservoirs in this area [28].

In addition, to analyze the source rock characteristics of well G20 in a more comprehensive and detailed way, three oil sand samples were selected for saturated hydrocarbon mass spectrometry analysis. The content of tricyclic terpane is low, the content of pentacyclic terpane is high, the content of $T_{S}$ is obviously higher than that of $T_{m}$, and the content of gammacerane is low or moderate. The content of pregnane 


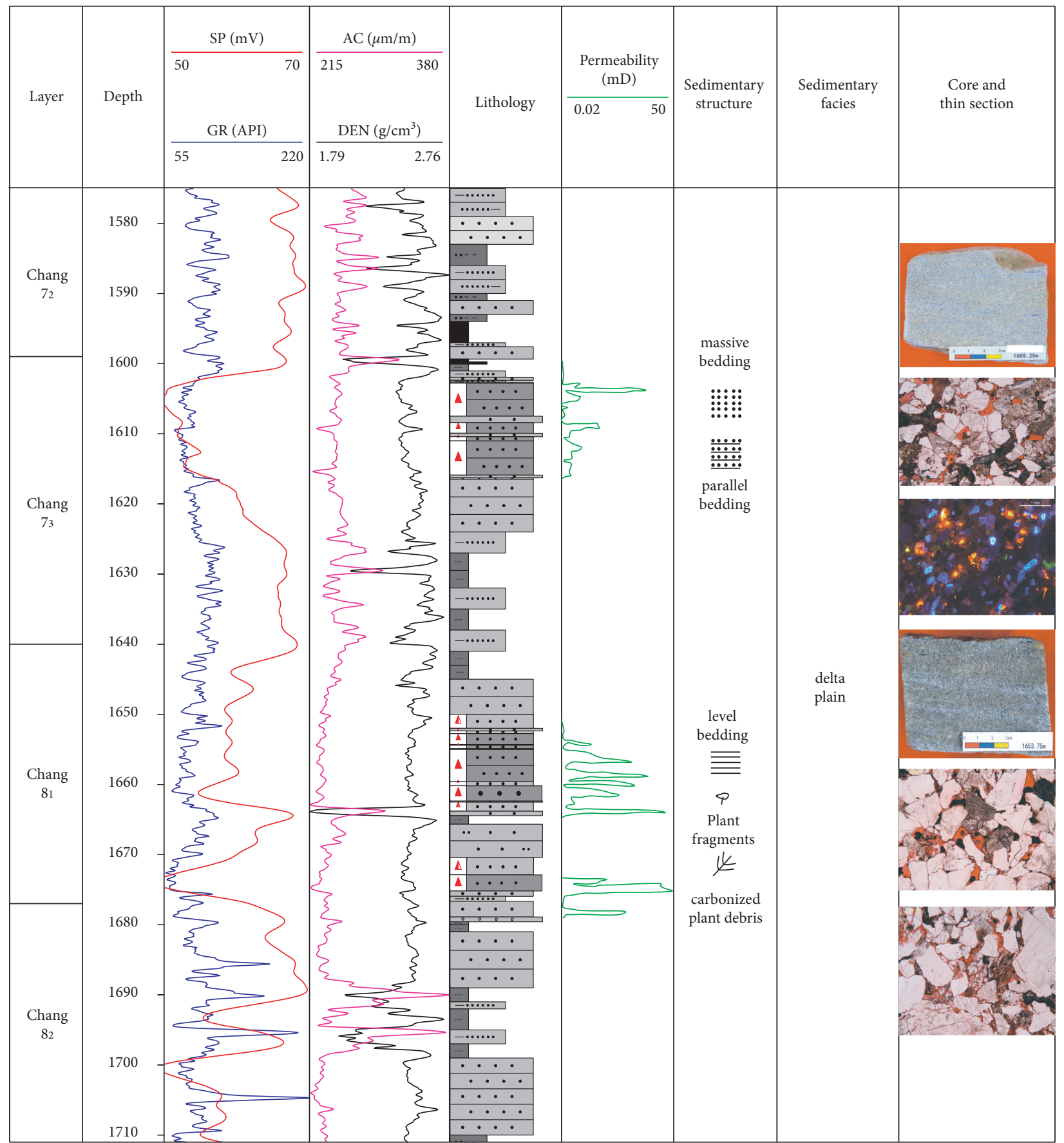

$\equiv$ mudstone

pelitic siltstone

E...: fine sandstone
Fi:日 siltstone

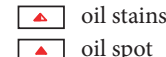

(a)

Figure 2: Continued. 


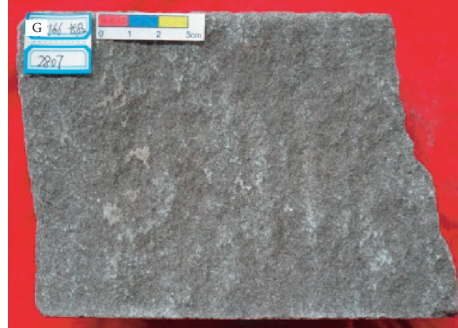

G166, Chang 8, 2807.0, dark gray fine sandstone, massive bedding

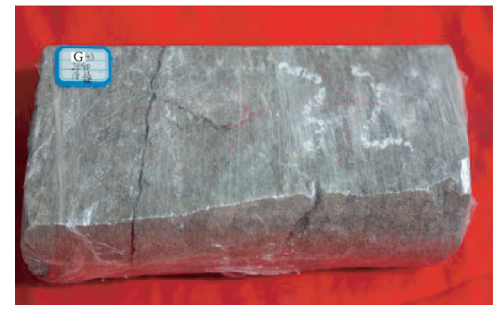

G43, Chang 8, $2680.0 \mathrm{~m}$, vertical crack, unfilled

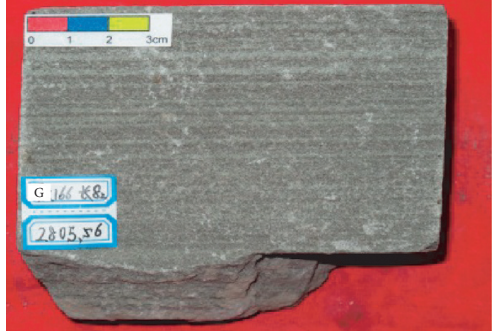

G166, Chang 8, $2805.6 \mathrm{~m}$, dark gray fine sandstone, parallel bedding

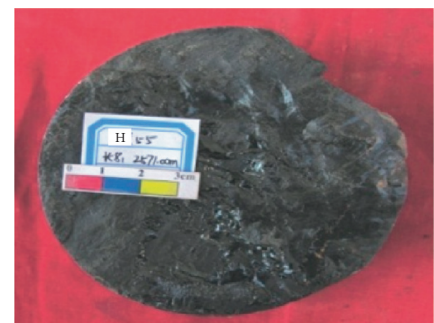

H55, Chang 8, $2571.0 \mathrm{~m}$, carbonized plant stem

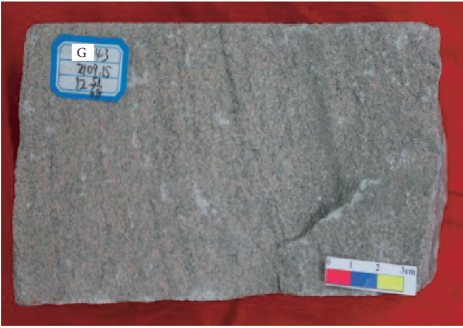

G43, Chang 8, $2109.2 \mathrm{~m}$, gray pack sand, cross-bedding

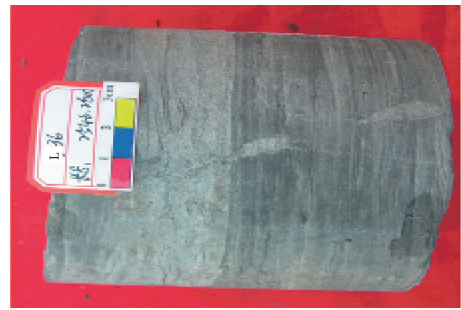

L36, Chang 8, $2546.3 \mathrm{~m}$, oblique wormhole

(b)

Figure 2: The sedimentary facies of well G20 (a) and typical rock sedimentary structure (b) in the study area.

was high; for regular sterane, $\alpha \alpha \alpha$ 20R sterane $\omega(\mathrm{C} 27)>\omega$ (C29), $\alpha \alpha \alpha 2 \mathrm{R} \mathrm{C27/C29} \mathrm{is} \mathrm{1.01,} \alpha \alpha \alpha 20 \mathrm{R}$ C28/C29 is 0.87, and pregnane + pregnane $/ \alpha \alpha \alpha$ 20R C29 is 1.37. C27, C28, and C29 have an asymmetric " $L$ " shape (Figure 5), which indicates that the crude oil source material of the Chang 8 member is mainly composed of low aquatic organisms of lacustrine facies and a small number of terrestrial higher plants; the value of $\alpha \alpha \alpha \mathrm{C} 29 \mathrm{~S} / \mathrm{S}+\mathrm{R}$ is 0.59 ; the value of $\mathrm{C} 29$ $\beta / \alpha \alpha+\beta \beta$ is 0.48 ; the value of $\alpha \alpha \alpha \mathrm{C} 31 \mathrm{~S} /(\mathrm{S}+\mathrm{R})$ is 0.41 ; and the thermal evolution degree is close to the equilibrium state. The crude oil has approached or reached the maturity stage [29], which is basically consistent with the analysis results of the mudstone in well G43 in the study area.

4.5. Reservoir Characteristics. The sandstone of the Chang 8 reservoir is mainly grayish white and grayish green; the lithology is mainly fine sandstone, followed by medium sandstone, with a small amount of siltstone and mudstone, mainly including lithic arkose, feldspathic lithic sandstone, and arkose. Among them, the detrital composition is mainly quartz, followed by feldspar and debris. The quartz content is generally $26 \%-45 \%$, with an average of $38.5 \%$; the feldspar content is generally $27 \%-43 \%$, with an average of $30.6 \%$; and the cutting content is generally $19 \%-40 \%$, with an average of 29.1\%. Clastic materials are divided into three types: medium to poor roundness, subangular to angular and mainly supported by particles, and heterobase. The cementation mode is mostly pore cementation, and contact cementation is less common. The cumulative probability curves of the grain size are mostly two-stage, in which the overall slope of the saltation times is large, the content is high, and the particle sorting is good; the overall slope of the suspended movement times decreases with the overall grain size of the saltation times, but the overall slope is still low, and the structure maturity is high. Therefore, the sandstone of the Chang 8 reservoir in the northwest Ordos Basin is the product of a sedimentary environment with relatively high water energy.

The Chang 8 reservoir is mainly siltstone formed by underwater distributary channel microfacies. The lithology is mainly arkose and lithic arkose siltstone, with a high content of an argillaceous matrix. A large number of casting thin section observations and a FE-SEM analysis show that the reservoir space mainly consists of intergranular pores and feldspar intragranular dissolved pores, with a small number of calcite cement solution pores, rock debris intragranular solution pores, authigenic mineral intergranular pores, clastic mineral intergranular pores, moldic pores, and microfractures. Chlorite is mostly present as a very thin film wrapped around debris, and the laumontite is slightly dissolved. The pore diameter is generally $20-80 \mu \mathrm{m}$ [30]. The diameter of the locally developed mold pores can reach more than $120 \mu \mathrm{m}$, and the diameter of the primary intergranular pores is generally less than $40 \mu \mathrm{m}$.

According to the statistics from 187 core porosity and permeability data points, the sandstone reservoir has poor physical properties, and the porosity is generally distributed in the range of $7.48 \%-17.98 \%$, with an average of $12.7 \%$. The permeability is mainly distributed in the range of $(0.45-9.80) \times 10^{-3} \mu \mathrm{m}^{2}$, with an average of $8.98 \times 10-3 \mu \mathrm{m}^{2}$, and the porosity is $5.39 \%$ (Figure 6 ). Thus, the Chang 8 reservoir is a low-porosity and low-permeability reservoir. 
TABLE 1: The trace elements and paleodepths of 8 mudstones from the Yanchang formation in the Yanchi area.

\begin{tabular}{|c|c|c|c|c|c|c|c|c|c|c|c|c|c|c|c|c|c|c|c|c|}
\hline \multirow{3}{*}{ Number } & \multirow{3}{*}{ Well } & \multirow{3}{*}{$\begin{array}{c}\text { Top } \\
\text { depth } \\
\text { of the } \\
\text { well } \\
(\mathrm{m})\end{array}$} & \multicolumn{17}{|c|}{ Element (mass fraction) } & \multirow{3}{*}{$\begin{array}{c}\text { Ancient } \\
\text { water } \\
\text { depth } \\
\text { (m) }\end{array}$} \\
\hline & & & $\mathrm{Pb}$ & Co & $\mathrm{Ni}$ & $\mathrm{V}$ & $\mathrm{Be}$ & $\mathrm{Sr}$ & $\mathrm{Ba}$ & Th & $\mathrm{U}$ & $\mathrm{La}$ & $\mathrm{Ce}$ & $\operatorname{Pr}$ & $\mathrm{Mn}$ & $\mathrm{P}$ & $\mathrm{Ca}$ & $\mathrm{Mg}$ & $\mathrm{TFe}$ & \\
\hline & & & $10^{-6}$ & $10^{-6}$ & $10^{-6}$ & $10^{-6}$ & $10^{-6}$ & $10^{-6}$ & $10^{-6}$ & $10^{-6}$ & $10^{-6}$ & $10^{-6}$ & $10^{-6}$ & $10^{-6}$ & $10^{-6}$ & $10^{-6}$ & $10^{-2}$ & $10^{-2}$ & $10^{-2}$ & \\
\hline 1 & $\begin{array}{c}\text { C51- } \\
1\end{array}$ & 2541.1 & 20.5 & 6.10 & 25.5 & 138 & 2.06 & 380 & 128 & 12.2 & 3.78 & 35.5 & 69.9 & 8.50 & 352.4 & 141 & 0.45 & 1.11 & 3.42 & 10.4 \\
\hline 2 & $\begin{array}{c}\text { C51- } \\
2\end{array}$ & 2575.6 & 18.6 & 13.4 & 34.7 & 138 & 1.88 & 326 & 401 & 10.9 & 3.39 & 28.3 & 58.3 & 7.32 & 587.7 & 1311 & 1.17 & 1.48 & 4.84 & 33.9 \\
\hline 3 & $\mathrm{C} 93$ & 2532.8 & 10.6 & 11.6 & 34.9 & 163 & 3.07 & 257 & 311 & 8.18 & 4.01 & 42.3 & 80.4 & 9.67 & 292.8 & 239 & 0.47 & & 2.95 & 27.3 \\
\hline 4 & $\mathrm{~F} 2$ & 2436.7 & 32.0 & 17.2 & 42.3 & 126 & 2.73 & 174 & 417 & 9.59 & 7.07 & 42.5 & 79.6 & 9.19 & 405.8 & 413 & 0.52 & 1.19 & 4.08 & 9.2 \\
\hline 5 & H36 & 2787.2 & 19.8 & 16.0 & 47.1 & 130 & 1.87 & 199 & 451 & 10.9 & 3.45 & 29.2 & 65.5 & 8.90 & 509.6 & 1278 & 1.65 & 1.56 & 5.33 & \\
\hline 6 & H39 & 2677.8 & 14.0 & 8.11 & 30.0 & 84 & 3.45 & 84.4 & 279 & 3.90 & 3.64 & 13.6 & 29.0 & 3.96 & 66.1 & 154 & 0.19 & 0.3 & & \\
\hline 7 & H51 & 3014.2 & 31.8 & 15.0 & 39.6 & 140 & 2.55 & 346 & 118 & 12.1 & 3.63 & 33.0 & 55.8 & 6.21 & 197.5 & 354 & 0.21 & 1.40 & & \\
\hline 8 & H54 & 2547.5 & 95.3 & 15.1 & 67.1 & 104 & 1.38 & 185 & 451 & 9.06 & 4.09 & 20.1 & 36.7 & 4.29 & 101.5 & 220 & 0.12 & 0.74 & 18.33 & 40.5 \\
\hline 9 & $\mathrm{H} 73$ & 2623.6 & 19.7 & 15.1 & 42.8 & 149 & 2.96 & 284 & 329 & 9.15 & 4.11 & 23.8 & 47.1 & 5.68 & 25.6 & 392 & 0.29 & 1.39 & 4.14 & 40.5 \\
\hline 10 & H83 & 2663.0 & 33.6 & 17.7 & 44.5 & 166 & 2.11 & 178 & 458 & 12.5 & 4.02 & 38.9 & 53.7 & 6.26 & 277.3 & 275 & 0.32 & 1.47 & 4.43 & 51.4 \\
\hline
\end{tabular}

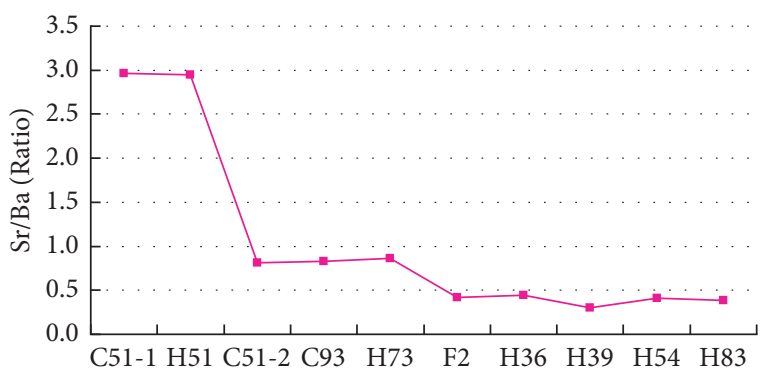

FIgure 3: Changes in the $\mathrm{Sr} / \mathrm{Ba}$ ratio of the Chang 8 reservoir of the Yanchang formation in the study area.

Eleven samples were observed under a microscope, and the luminescent asphalts in the oil sands of well G20 are mainly composed of oiliness, gum, asphaltene, and carbonaceous asphalts, mainly saturated hydrocarbons, cycloalkanes, and other light soluble hydrocarbons. They are mainly present due to interparticle adsorption and pore surface adsorption, a small amount of pore throat-like and pore surface films is formed, and a corner-like occurrence can be seen. The fluorescence is yellow white, yellow green, and brown orange. Among them, the fluorescence intensity of $1652.5-1675.2 \mathrm{~m}$ is weak to moderately strong, and the oil saturation of the nuclear magnetic resonance analysis is $11.47 \%-43.59 \%$, with an average of $27.84 \%$. The logging of this well shows oil traces and oil spot, and the core oil smell is obvious.

\section{Discussion}

Well G20 is located in the Yanchi area that crosses the Tianhuan depression and the western margin thrust belt, in which the faults are well developed. Compared with the center of the basin, the Chang 7 source rocks in this area are not well developed [31-33], but still have certain hydrocarbon generation capacity. Meanwhile, the reservoir characteristics show that the area has the conditions for oil enrichment. However, Well G20 has produced water after fracturing. Combined with the regional geological background, the main controlling factors of the Chang 8 oil reservoir in the Yanchi area are discussed.

5.1. Sedimentary Evolution. The Ordos Basin was a large inland freshwater lake basin in the Late Triassic and experienced a complete process of lake transgression and lake retreat. The Chang 10 to Chang 7 members represent lake transgression, Chang 6 to Chang 2 members represent lake regression, and Chang 1 member represents lake retreat. Chang 7 is the most important source rock from the $\mathrm{Me}$ sozoic in the basin.

The Late Triassic was the most important stage for the development of the geological structure in the Ordos Basin, and it was also one of the extremely important periods of oilforming systems. The Yanchang Formation of the Upper Triassic is a complete sedimentary cycle composed of transgressive and retrograde sequences. Chang 8 and Chang 7 represent the lake transgression stage. The lake basin expanded gradually, the water body deepened gradually, and the sediment in the longitudinal direction changed from coarse to fine, with that in the Chang 7 reaching the maximum. In the early stage of the deposition of the Chang 8 oil-bearing member, the lateral extent of the water was wide, and the water depth was large. With the gradual shallowing of the water body and the supply of abundant sediments, the lake basin shrank, and the water body became shallower; in the middle stage of the deposition of the Chang 8 oil-bearing member, a large lakeside swamp area and coal were developed.

Many vertical or large-angle inclined wormholes have been found in the Chang 8 oil-bearing member and other places in southern Jiyuan, indicating a turbulent shallow water oxygen-rich sedimentary environment. In the middle of the lake basin, the water body gradually expanded, collapsed, and rapidly expanded again in the late sedimentary stage of the Chang 8 oil-bearing member, reaching the peak stage of the basin deposition [34]. From the characteristics of the sedimentation and paleolake water depth interpreted at 


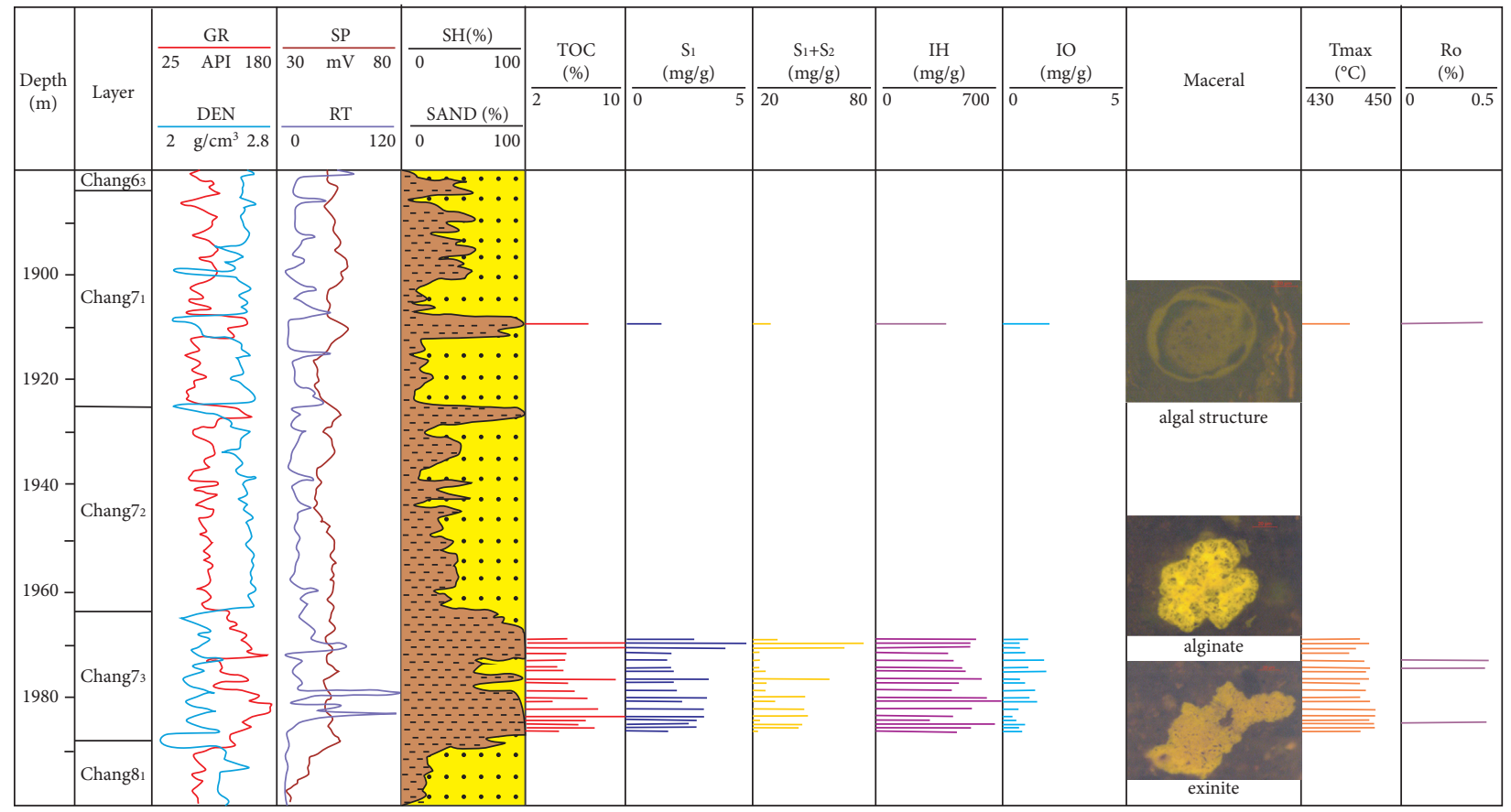

Figure 4: The comprehensive geochemical profile of well G43.

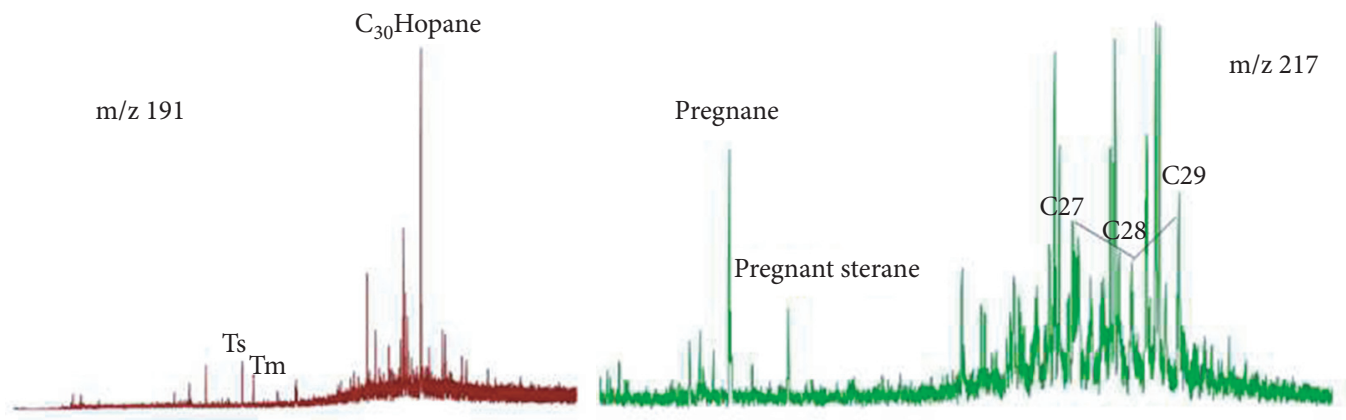

FIGURE 5: Mass spectrum of Chang 8 saturated hydrocarbons in well G20.

G20, the well had a dry climate during the deposition of the Chang 8 member, the paleolake water depth was $10-50 \mathrm{~m}$, and the river channel sand body in the delta plain was developed. Due to the many river channel swings and lateral migrations, multistage superimposed river channel sand bodies can be seen in the rock core, and well-preserved plant roots, (carbonized) plant stems, carbonaceous mudstone, and coal lines can be found. Generally, the sedimentary evolution characteristics of the Yanchi area in Northwest China are basically consistent with those of the whole basin (Figure 7).

5.2. Tectonic Movement. The study area is located at the intersection of several tectonic units in the western Ordos Basin. The structural evolution has transformed four times, including in the late Indosinian, the main Yanshanian, the late Yanshanian, and the Himalayan, and they have complex and diverse structural features (Figure 8). The Triassic Yanchang Formation strata studied in this paper were deposited in the sedimentary period of the cratonic basin before tectonic uplift and reconstruction at the end of the Indosinian, which corresponded to a weak compressive stress environment.

Since the deposition of the Yanchang Formation, the study area has been affected by the Yanshanian and $\mathrm{Hi}$ malayan tectonic stress fields. From the Middle and Late Jurassic, due to the oblique subduction of the Pacific plate to the Eurasian plate, the basin as a whole was in a NE-trending sinistral compression tectonic environment. Under the influence of the tectonic stress field, the eastern part tilted westward as a whole, and thrusting and napping occurred many times in the west. A large number of thrust structures developed west of the Tianhuan depression, and nose-like structures inclined to the west developed in the east. After entering the Himalayan period, the collision between the Indian Ocean plate and the Eurasian plate and the westward subduction of the Pacific plate led to changes in the mechanical properties of the basin. Affected by the southwest compressive stress and the north-south dextral shear stress, 


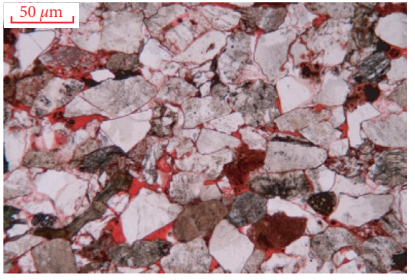

Intergranular pore, intergranular dissolved pore, zeolite dissolved pore and microfracture, $1615.15 \mathrm{~m}$

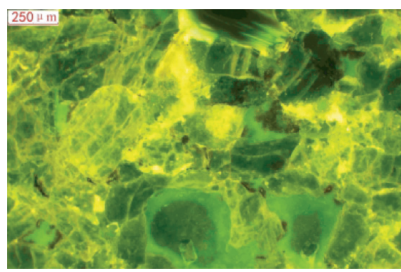

The fluorescence is yellow, brown, and orange, and the luminescence intensity is medium bright, $1653.75 \mathrm{~m}$

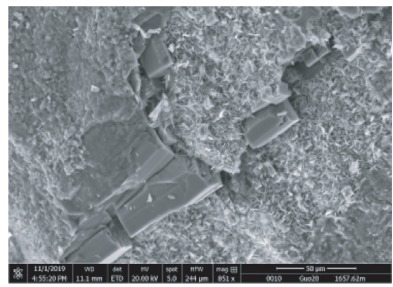

Part of the grain surface has a chlorite membrane, and the intergranular pore throat is cemented with albite, $1657.62 \mathrm{~m}$

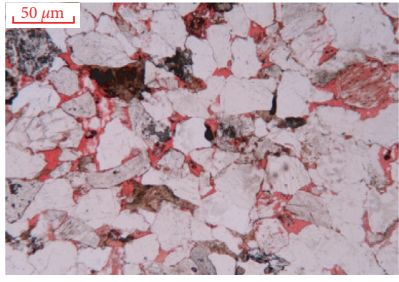

Residual intergranular pore, zeolite dissolved pore and feldspar dissolved pore, $1655.61 \mathrm{~m}$

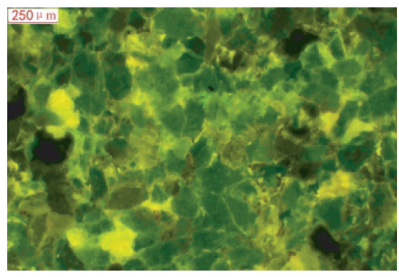

The fluorescence is yellow, brown, and orange, and the intensity is dark, $1655.26 \mathrm{~m}$

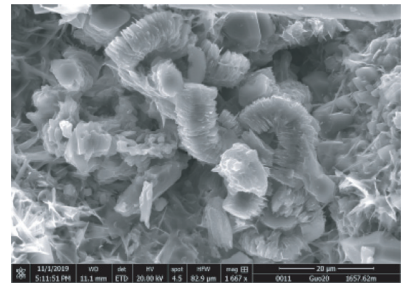

Kaolinite clay filling can be seen in a few pores, $1657.62 \mathrm{~m}$

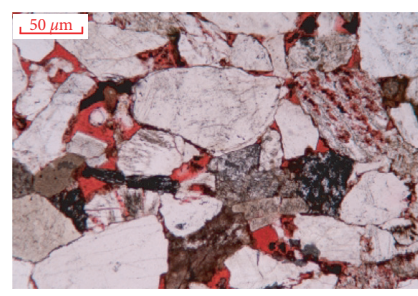

Residual intergranular pore and dissolution pore $1658.13 \mathrm{~m}$

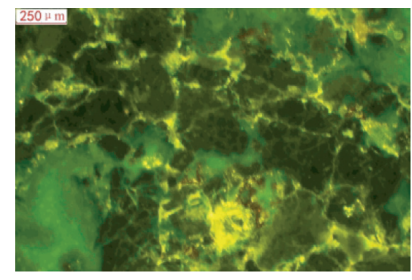

The fluorescence is yellow

white to brown orange, and the intensity is dark, $1662.62 \mathrm{~m}$

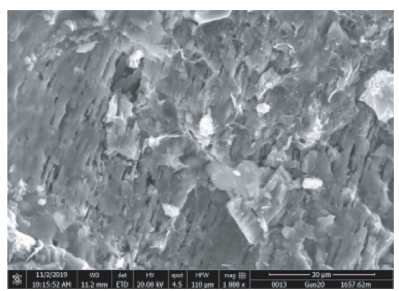

A small amount of feldspar clastic particles are dissolved to produce solution pores, $1657.62 \mathrm{~m}$

Figure 6: Thin section, fluorescence, and SEM images of samples from well G20.

the NW-SE tensile stress coexisted with the NE-SW direction compressive stress, resulting in a series of fault basins. At this time, the Majiatan Yujialiang area in Yanchi, Northwest China, formed a nearly north-south thrust nappe and associated thrust faults, with a large scale and a flowerlike structure on the profile (Figure 9). Around the basin, normal faults began to develop in the Gufengzhuang area, and a series of NW-SE-trending normal faults were formed in the inner part of the Tianhuan depression. The fault throws of these faults are small, and only the Yanchang Formation and the Yan'an Formation are offset [35]. The Yanshanian and Himalayan tectonic movements established a paleotectonic framework characterized by steep west, gentle east, and east-west differentiation, but the tectonic stress field also provided a dynamic source for the formation of faults $[36,37]$.

According to the observation of oil and gas inclusions in the reservoir of the study area, there are abundant fluid inclusions in the Chang 8 sandstone reservoir, which are mainly distributed in quartz grain fractures, quartz grain enlarged edges, and quartz particle surfaces, and there are few fluid inclusions in the late spar calcite. The homogenization temperature reflects the temperature of the mineral trapping fluid and is mainly distributed at $80 \sim 100^{\circ} \mathrm{C}$ and $120 \sim 130^{\circ} \mathrm{C}$ (Figure 10). The comprehensive study of the reservoir forming stages shows that there are three stages of hydrocarbon accumulation in the reservoir: the small-scale oil and gas filling stage when the maturity of the source rock was low from the middle Late Jurassic to the early Cretaceous, the main reservoir forming stage of large-scale oil and gas filling at the end of the Early Cretaceous, and the Late Cretaceous uplift and oil and gas migration and accumulation period. The Indosinian and Yanshanian faults formed before or around the time of the maximum reservoir forming period, which is relatively favorable for reservoir forming, while the Himalayan faults usually destroyed the earlier formed reservoirs or form secondary oil and gas reservoirs [38, 39].

5.3. Analysis of Water Production. The burial depths of the Chang 8 reservoir at well G20 are 1649 11661 $\mathrm{m}$ and $1671 \sim 1674 \mathrm{~m}$, and the oil layer is thick. The reservoir resistance is $30.2 \sim 59.5 \Omega \cdot \mathrm{m}$, with an average of $41.2 \Omega \cdot \mathrm{m}$, and 


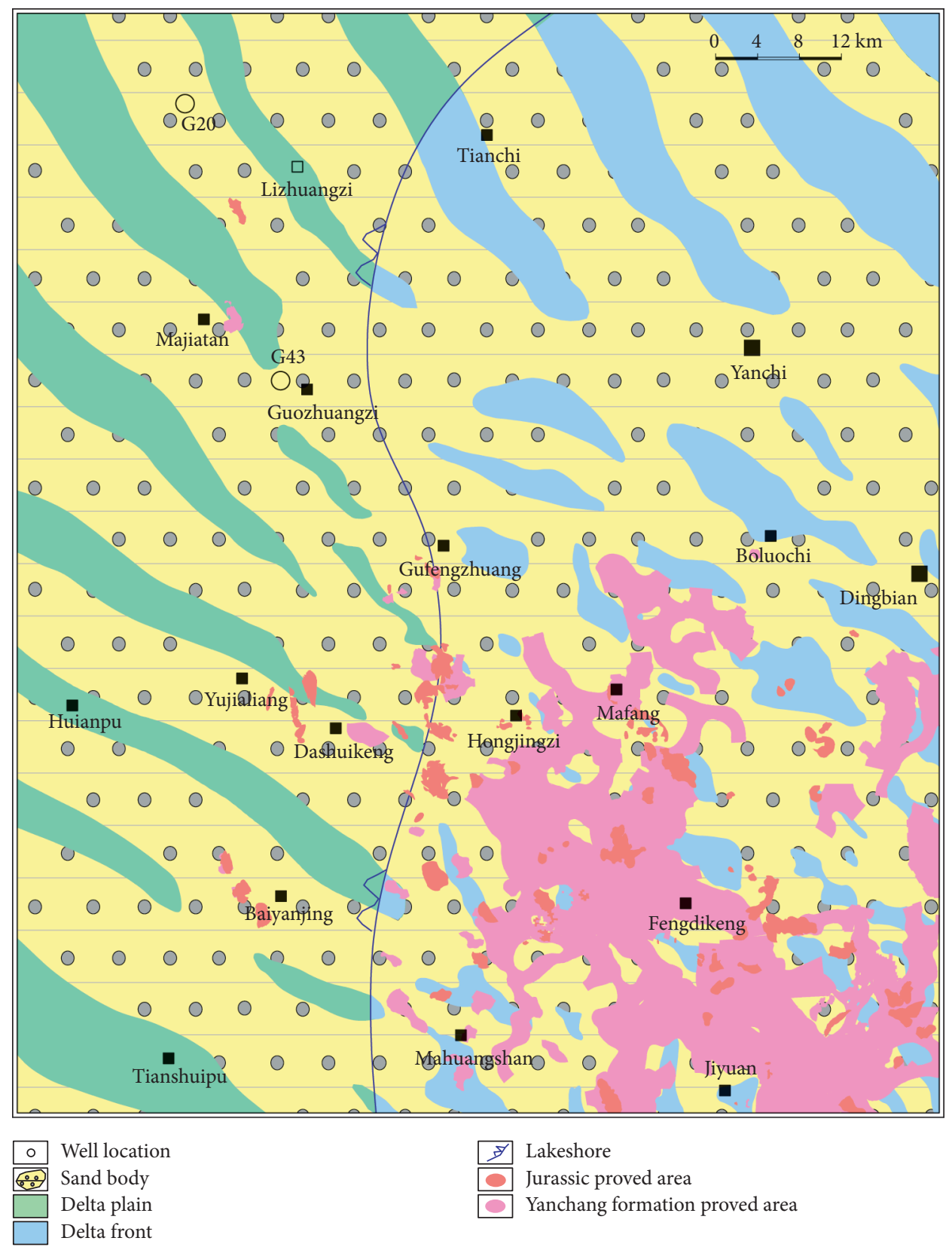

Figure 7: Sedimentary facies map of the Chang 8 member of the Yanchang formation in the northwest Ordos Basin.

the time difference is $223.7 \sim 238.6 \mu \mathrm{s} / \mathrm{m}$, with an average of $228.7 \mu \mathrm{s} / \mathrm{m}$. Generally, there is a good positive correlation between reservoir display and resistivity. The higher the resistance is, the better the relative oil content of the core, and the easier it is to produce oil during testing. According to the previous analysis, the physical and electrical parameters of the well match well, and the production test should obtain industrial scale oil, but water is produced in the later fracturing.

Further analysis shows that well G20 is located in the northwest sedimentary system, which is a shallow-water deposit that deposited in a dry climate and with a sufficient material source supply, which is conducive to the formation of distributary channel sand bodies distributed in a large area and good reservoir conditions. The adjacent Jiyuan area in the middle of the lake basin has an average permeability of $8.7 \%$ to $0.56 \%$. The porosity of well G20 is $12.7 \%$, and the permeability is greater than $8.98 \times 10^{-3} \mu \mathrm{m}^{2}$. The reservoir physical properties are obviously better than Jiyuan area, the oil and gas storage space is large, and fluid easily flows. From the analysis of hydrocarbon-generation conditions, the source rocks near the well are also developed, and the mudstone thickness is $5-10 \mathrm{~m}$. The mudstone has a certain hydrocarbon-generation capacity, which is weak compared with that in the center of the basin. Combined with the regional sedimentary characteristics and buried thermal evolution history, the water production of the well is due to the insufficient hydrocarbon generation 


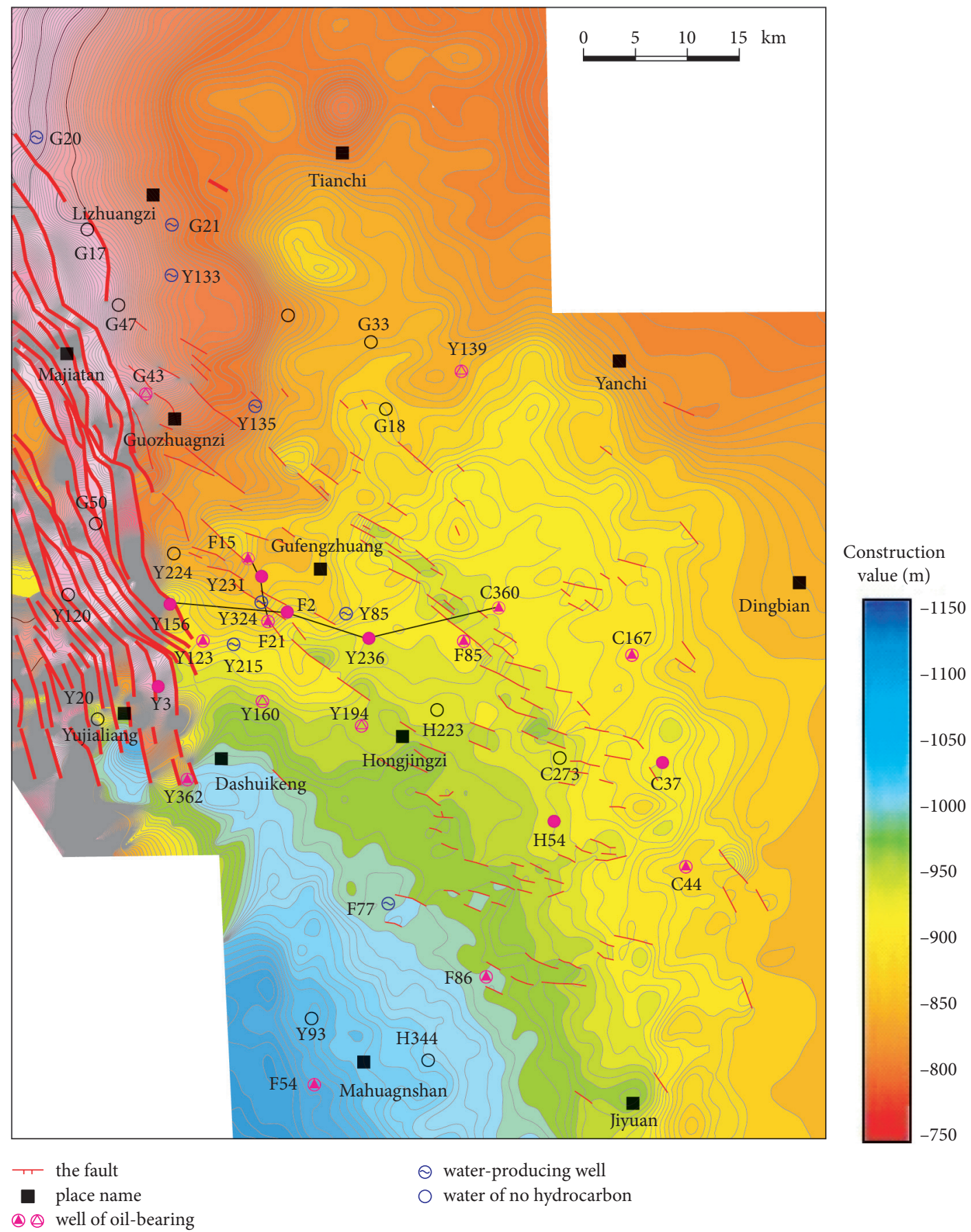

Figure 8: Contour map of the top of the Chang 8 structure of the Yanchang formation in the northwest Ordos Basin.

of the overlying Chang 7 source rock, the good reservoir physical properties, the presence of a horizontal continuous sand body, and the lack of dense layers such as mudstone. It is difficult for Chang 8 reservoir to accumulate much hydrocarbon. In addition, due to the influence of tectonic movement in this area, multistage faults are developed, light hydrocarbon components escape, and heavy components are enriched to form residual oil reservoirs, which result in the good oil-bearing properties observed in the core.
Therefore, the observation of dark and oil-bearing layers in the cores does not represent the true production potential. The impact of later structures on oil and gas migration, including fractures and faults, should be considered. Especially for low-permeability reservoirs with insufficient hydrocarbon supply capacity, when exploring oil and gas, we should analyse objectively with thick sand layers and good oil-bearing displays; because there is no lithologic or only low-amplitude structural traps, oil may not be produced even if the reservoir physical properties are good. This 


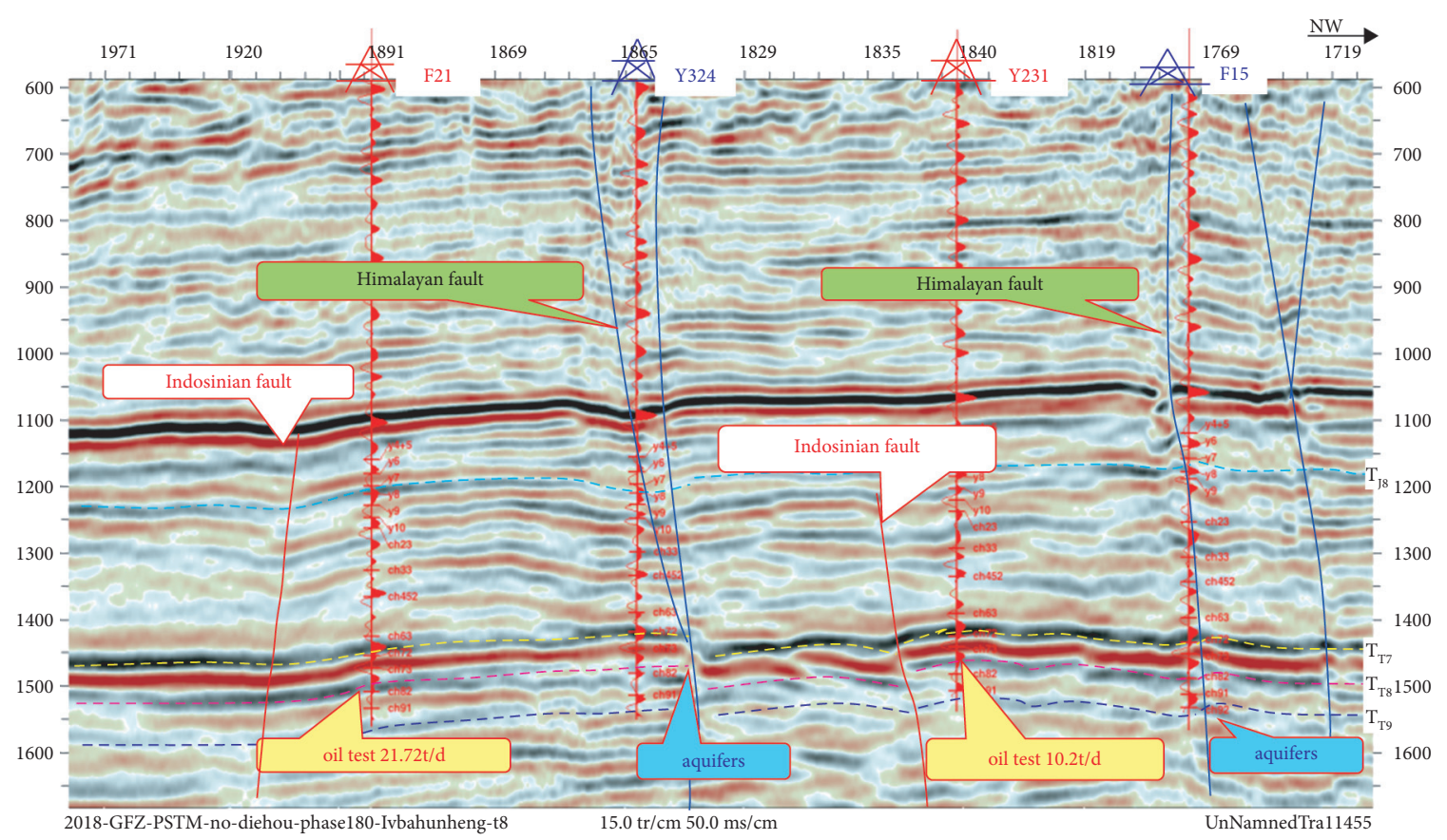

FIGURE 9: Seismic profile from well Feng21 to well Yan231 in the Yanchi area (the profile position is shown in Figure 8).

understanding has important guiding significance for oil and gas reservoir exploration under similar geological conditions.

5.4. Favorable Exploration Direction. According to the distribution of the regional reservoir characteristics, the Chang 8 oil reservoir in the Yanchi area can be divided into two types: structural reservoir and structural-lithologic reservoir (Figure 11). The specific characteristics are as follows.

Structural reservoir: controlled by large faults, microfaults and fault-related folds are developed, and oil migrates vertically or horizontally through large faults and fractures. Fault blocks and structural reservoirs are formed at the structural highs, corresponding to a small scale, strong concealment, and high production. They are mainly distributed in Majiatan, Gufengzhuang, and other areas. At the same time, due to the good transportation system developed, Chang 4+5, Chang 9, and other reservoirs have also developed.

Structural-lithologic reservoir: the oil and gas mainly comes from the Tianhuan depression, which is to the east. During the hydrocarbon expulsion period of the source rocks in the Late Cretaceous, part of the generated oil and gas migrated vertically to sand bodies with good physical properties through microfaults, and some of the oil and gas further migrated to the high points of the microstructures or the upward dip pinch out points of the sand bodies. The Chang 8 oil reservoir is large in scale, and its formation was controlled by changes in the sedimentary sand body, the reservoir properties and the low-amplitude structures in particular $[40,41]$. This type of reservoir is mainly distributed in Mafang and other areas on the east side of the Tianhuan depression, such as the C360 reservoir.

The Yanchi area is located in the northwest of the basin. The Chang 7 source rock is thick in the south and thin in the north. In the Guozhuangzi-Lizhuangzi line, the source rock gradually becomes thinner, but it still has a certain hydrocarbon-generation capacity, and the overall oil and gas filling capacity is not strong [42]. Affected by peripheral uplift and tectonic activity, faults and fractures are relatively developed. The channel sand bodies are horizontally connected and vertically stacked in multiple layers. The oil and gas generated by the Chang 7 member migrates to the underlying Chang 8 strata and forms a reservoir in the relatively high part of the structure or the inner ring of a low-amplitude structure. The Chang 8 sand body in the study area has a considerable thickness, good reservoir physical properties, and stable distribution along the horizontal direction with long extended distance. If there is no mudstone or other dense barrier, no lithologic traps are formed, and the phenomenon of oil-bearing cores but water production in well testing often occurs. In contrast, hydrocarbon can be accumulated easily in a small-scale sand body if the overlying stratum of mudstone acts as a seal. In summary, in addition to the source rock, sedimentation, and reservoir conditions, the formation of the Chang 8 reservoir in the Yanchi area is controlled by trap and preservation conditions. According to the reservoir types and distribution characteristics of this area, the main direction of oil and gas exploration in the future is in areas with lithologic traps, low-amplitude structural traps and favorable preservation conditions. 

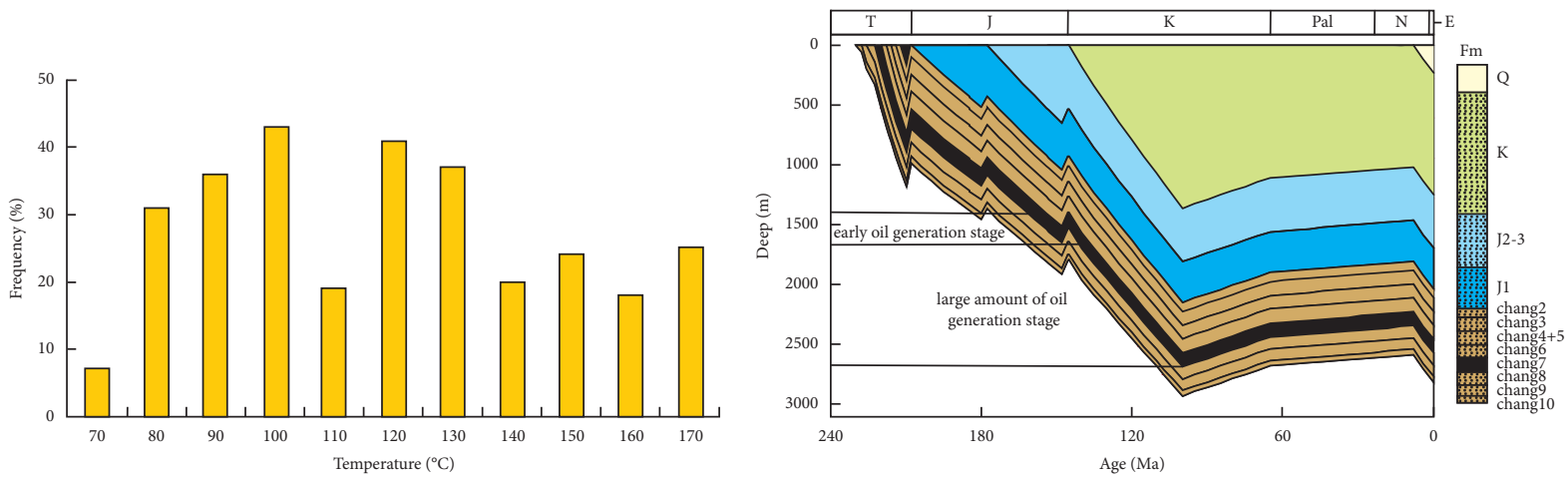

FIGURE 10: The homogenization temperature and burial history of inclusions in the study area (revised according to reference [38]).

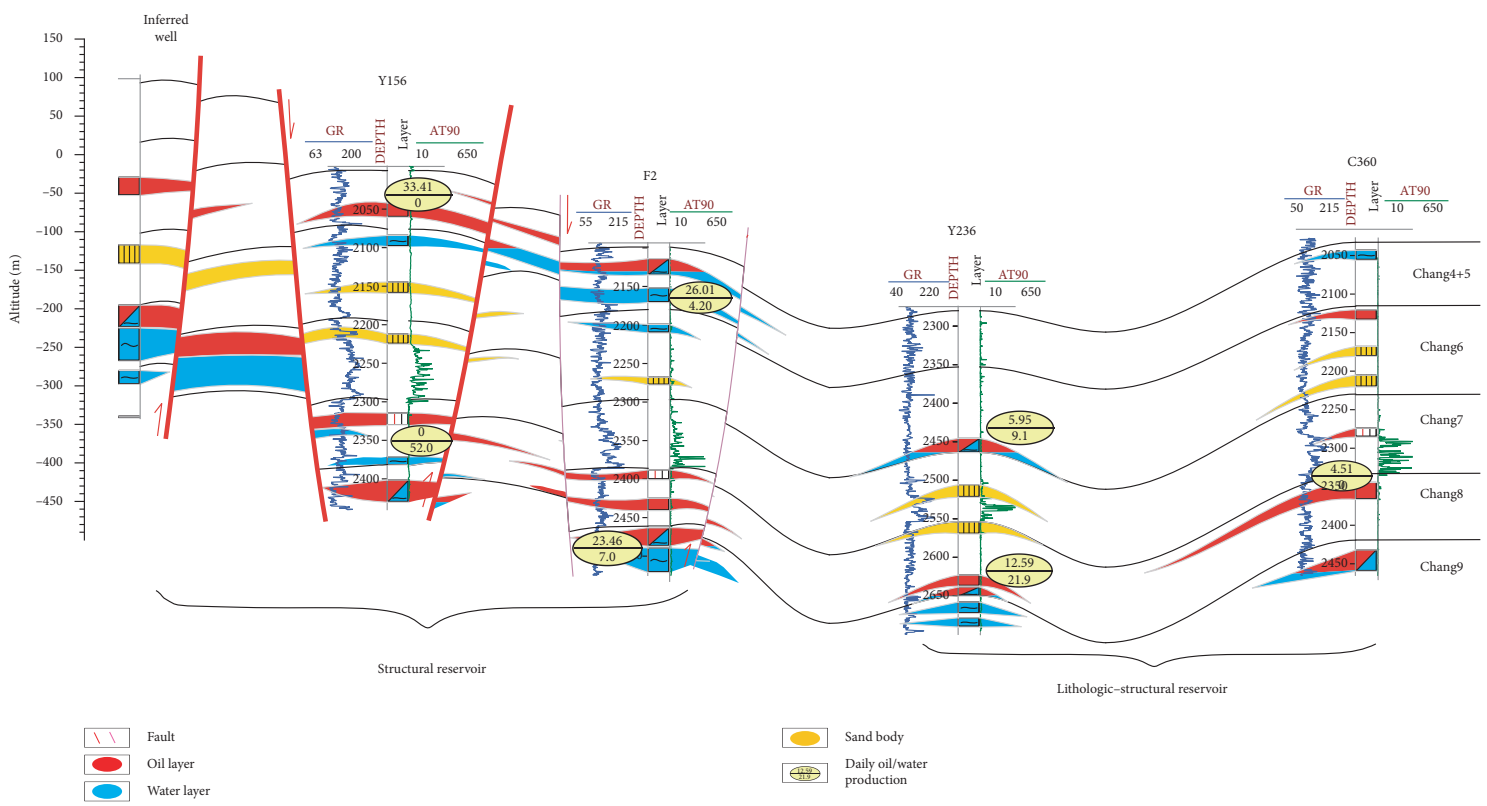

FIGURE 11: Distribution of main reservoir types in the Yanchi area of the northwest Ordos Basin (the profile position is shown in Figure 8).

\section{Conclusions}

(1) The main lithologies encountered in well G20 in the Chang 8 reservoir is argillaceous siltstone, silty mudstone, and a small amount of gravelly sandstone. Massive bedding, parallel bedding, and wedge-shaped cross-bedding are developed. A small amount of carbonized plant fragments are distributed along the bedding planes. The SP curve is box-shaped or nearly bell-shaped, and the GR curve has a low amplitude and little changes. The Chang 8 reservoir was deposited in a turbulent sedimentary environment with high water energy and is a delta plain subfacies.

(2) The overall water body range was large, and the slope was gentle, which was favorable for the development of the distributary channel sand bodies in the delta plain or in the delta front. The Sr/Ba ratio in the mudstone ranges from 0.30 to 2.97 , with an average value of 1.04. It corresponds to a brackish lake with a dry climate and has easily formed the large-scale distribution of the observed sedimentary sand bodies.

(3) The Chang 8 sandstone reservoir in the Yanchang Formation has a fine lithology and a high shale content. The reservoir space is mainly intergranular pores and feldspar intragranular dissolved pores. The average porosity is $12.7 \%$, and the average permeability is $8.98 \times 10^{-3} \mu \mathrm{m}^{2}$. It is a low-porosity and low-permeability reservoir. The Chang 7 source rocks belong to type I-II1, with an average TOC content of $5.99 \%$ and an average Ro of $0.48 \%$, which have certain hydrocarbon-generation potential.

(4) Due to no lithologic traps or low-amplitude structural traps, the well G20 produced water in testing. The Chang 8 oil reservoir in the Yanchi area can be divided into structural reservoir and structurallithologic reservoir. The former has a small scale with high oil production, and the latter has a large scale controlled by the sand bodies distribution, reservoir physical properties, and low-amplitude structures. 
Future exploration should ideally not focus on "thick sand belt" and "reservoir sweet spot," but instead target areas with lithologic traps, low-amplitude structural traps, and favorable preservation conditions.

\section{Data Availability}

The data used to support the findings of this study are included within the article.

\section{Conflicts of Interest}

The authors declare that they have no conflicts of interest.

\section{Acknowledgments}

This work was supported by the National Science and Technology Major Projects (grant nos. 2016ZX05050 and 2017ZX05001002-008) Natural Science Foundation of Shaanxi Province (grant no. 2020JQ-356).

\section{References}

[1] W. H. Li, J. G. Pang, H. X. Cao, X. Li, and R. G. Wang, "Depositional system and paleogeographic evolution of the late triassic Yanchang stage in Ordos Basin," Journal of Northwest University (Natural Science Edition), vol. 39, no. 3, pp. 501-506, 2009.

[2] X. B. Li, Q. L. Cheng, H. Q. Liu, Y. R. Wan, L. H. Wei, and J. B. Liao, "Features of sandy debris flows of the Yanchang formation in the Ordos Basin and its oil and gas exploration significance," Acta Geologica Sinica (English Edition), vol. 85, no. 5, 2011.

[3] M. C. Hou, X. Li, and M. Deng, "Study on the sedimentary environment of Chang 8-6 oil-bearing formations of Yanchang formation in huanxian area, Ordos Basin," Journal of Chengdu University of Technology (Science \& Technology Edition), vol. 38, no. 3, pp. 241-248, 2011.

[4] L. C. Ma, L. Y. Zhang, Z. X. Wang, X. G. Zhou, C. L. Li, and $X$. Chen, "Discussing the oil-control effects of the north latitudinal $38^{\circ}$ belt in central part of the Ordos Basin," Acta Geologica Sinica-English Edition, vol. 89, no. 2, 2015.

[5] J. W. Cui, R. K. Zhu, S. Li, Y. L. Qi, X. Z. Shi, and Z. G. Mao, "Development patterns of source rocks in the depression lake basin and its influence on oil accumulation: case study of the Chang 7 member of the Triassic Yanchang formation, Ordos Basin, China," Journal of Natural Gas Geoscience, vol. 4, no. 4, 2019.

[6] Z. L. Ren, W. H. Li, Y. Liang et al., "Tight oil reservoir formation conditions and main controlling factors of Yanchang formation in southeastern Ordos Basin," Oil \& Gas Geology, vol. 35, no. 2, pp. 190-198, 2014.

[7] A. Shen, Y. Liu, X. Wang, B. Cai, C. He, and S. Liang, "The geological characteristics and exploration of continental tight oil: an investigation in China," Journal of Petroleum Exploration and Production Technology, vol. 9, no. 3, pp. 1651-1658, 2019.

[8] L. R. Luo, W. Z. Zhang, and K. Wu, "Origin of Chang 8 oil reservoir in jiyuan region of Ordos Basin," Journal of Yanan University(Natural Science Edition), vol. 31, no. 3, pp. 89-94, 2012.
[9] M. J. Chu, S. X. Li, X. Y. Liu, X. Deng, and Z. Guo, “Accumulation mechanisms and modes of Yanchang formation Chang 8 interval hydrocarbons in Ordos Basin," Acta Sedimentologica Sinica, vol. 31, no. 4, pp. 683-692, 2013.

[10] S. J. Chen, J. G. Lu, and J. L. Yao, "Characteristics of reservoir formation and the controlling factors of Chang 8 oil bearing formation in huaqing area of Ordos Basin," Acta Sedimentologica Sinica, vol. 30, no. 6, pp. 1130-1139, 2012.

[11] S. Xia, C. G. Huang, J. Cui, and Y. F. Li, "Reservoir space type and storage capacity of oligocene lacustrine carbonate in the Yingxi area of western Qaidam Basin, China," Carbonates and Evaporites, vol. 34, no. 3, pp. 1074-1094, 2019.

[12] C. N. Zou, Z. Yang, S. Z. Tao et al., "Continuous hydrocarbon accumulation over a large area as a distinguishing characteristic of unconventional petroleum: the Ordos Basin, NorthCentral China," Earth-Science Reviews, vol. 126, pp. 358-369, 2013.

[13] W. Z. Zhao, B. Zhang, X. M. Wang et al., "Differences in source kitchens for lacustrine in-source and out-of-source hydrocarbon accumulations," Petroleum Exploration and Development, vol. 48, no. 3, pp. 464-475, 2021.

[14] Z. C. Sun and Q. Y. Xie, "Evolution characteristics of superposed basin and its prtroleum significance: example for Ordos Basin," Experimental Petroleum Geology, vol. 2, no. 1, pp. 13-21, 1980.

[15] H. Yang, W. Z. Zhang, and H. B. Lin, "Origin of Chang 10 oil reservoir in northern Shaanxi region of Ordos Basin," Geochimica, vol. 39, no. 3, pp. 274-279, 2010.

[16] X. Hui, Y. D. Zhao, and X. Z. Shao, "The geological conditions, resource potential, and exploration direction of oil in Ordos Basin," Marine Oil and Gas Geology, vol. 24, no. 2, pp. 14-22, 2019.

[17] J. H. Fu, Z. Q. Guo, and X. Q. Deng, "Sedimentary facies of the Yanchang formation of upper triassic and petroleum geological implication in southwestern Ordos Basin," Jorunal of Palaeogeography, vol. 7, no. 1, pp. 34-44, 2005.

[18] J. G. Yang, L. Wang, S. Li et al., "The influence of reservoir composition on the pore structure of continental shale: a case study from the qingshankou formation in the Sanzhao Sag of northern Songliao basin, NE China," Geofluids, vol. 2021, Article ID 5869911, 21 pages, 2021.

[19] M. Wang, H. M. Tang, H. X. Tang et al., "Impact of differential densification on the pore structure of tight gas sandstone: evidence from the permian Shihezi and Shanxi formations, eastern Sulige gas field, Ordos Basin, China," Geofluids, vol. 2019, Article ID 4754601, 25 pages, 2019.

[20] C. L. Li, L. L. Wang, and P. P. Chen, "Sedimentary environment and geochemical characteristics of Shahejie formation in huimin Sag, Bohai bay basin, China," Arabian Journal of Geosciences, vol. 13, no. 21, 2020.

[21] S. F. Yang, Z. D. Ba, N. Wang et al., "Diagenetic evolution and its impact on reservoir quality of tight sandstones: a case study of the triassic Chang 6 member, Ordos Basin, northwest China," Marine and Petroleum Geology, vol. 117, Article ID 104360, 2020.

[22] X. J. Zhang, Y. F. Fan, J. J. Zhang, and G. C. Wang, "Microelement and geologic significance of Yanchang formation in Fuxian area, Ordos Basin," Xinjiang Petroleum Geology, vol. 25, no. 5, pp. 483-485, 2004.

[23] Y. M. Fan, H. J. Qu, H. Wang, X. C. Yang, and Y. W. Feng, "The application of trace elements analysis to identifying sedimentary media environment:a case study of late triassic strata in the middle part of western Ordos Basin," Geolgoy in China, vol. 39, no. 2, pp. 382-389, 2012. 
[24] T. F. Wang, Z. K. Jin, and M. J. Chu, "Sedimentary environment of the Chang 6 oil-bearing interval of upper triassic Yanchang formation in jiyuan area, Ordos Basin: evidences from geochemical data," Journal of Alaeogeography (Chinese Edition), vol. 21, no. 3, pp. 505-516, 2019.

[25] S. S. Luo and X. Yin, "Study on the sedimentary facies of Chang 8 oil group of Yanchang formation in jiyuan area of Ordos Basin," Journal of Oil and Gas Technology, vol. 30, no. 4, pp. 5-9, 2008.

[26] Z. J. Xu, L. F. Liu, T. G. Wang et al., "Characteristics and controlling factors of lacustrine tight oil reservoirs of the triassic Yanchang formation Chang 7 in the Ordos Basin, China," Marine and Petroleum Geology, vol. 82, pp. 256-296, 2017.

[27] A. Ahmed, T. Khan, S. Jahandad, M. Hakimi, A. Lashin, and N. Zainal Abidin, "Organic geochemistry indicates sourcerock characteristics and hydrocarbon potential: a case study from early cretaceous sembar formation, southern Indus Basin, Pakistan," Arabian Journal of Geosciences, vol. 13, no. 23, 2020.

[28] S. L. Xi, W. Z. Gang, and Q. Y. Yang, "Organic geochemistry and sedimentary paleoenvironment of Chang 7 source rocks in Yanchi-Dingbian area, Ordos Basin," Geoscience, vol. 33, no. 4, pp. 890-901, 2019.

[29] S. Liu, G. Gao, T. Qu et al., "Implications of organic matter source and fluid migration from geochemical characteristics of stylolites and matrix in carbonate rocks: a case study from the carboniferous and the rdovician in the Sichuan Basin, SW China," Journal of Petroleum Science and Engineering, vol. 186, Article ID 106606, 2020.

[30] B. Ma, S. Yang, Q. Kong et al., "Diagenetic facies quantitative evaluation of low-permeability sandstone: a case study on Chang 82 reservoirs in the Zhenbei area, Ordos basin," Energy Exploration \& Exploitation, vol. 36, no. 3, pp. 414-432, 2018.

[31] X. Liu, F. Wang, B. Liu et al., "Factors controlling hydrocarbon accumulation in jurassic reservoirs in the southwest Ordos Basin, NW China," Acta Geologica Sinica-English Edition, vol. 94, no. 2, pp. 467-484, 2020.

[32] R. Z. Yang, X. Z. Zhao, and H. J. Li, "Evolution characteristics of the upper paleozoic source kitchen and its controlling effects on hydrocarbon accumulation in the paleozoic petroleum system in Huanghua depression, Bohai Bay Basin, China," Journal of Petroleum Science and Engineering, vol. 193, Article ID 107415, 2020.

[33] L. X. Dou, J. G. Hou, Y. M. Liu, L. Zhang, S. Song, and $\mathrm{X}$. Wang, "Sedimentary in fill of shallow water deltaic sand bodies controlled by small-scale syndepositional faults related paleogeomorphology: insights from thepaleogene Shahejie formation in the Dongying depression, Bohai Bay Basin,Eastern China," Marine and Petroleum Geology, vol. 118, Article ID 104420, 2020.

[34] X. C. Yang, H. J. Qu, and Z. L. Cui, "Sedimentary facies of Chang8 oilbearing Formation in wuqi-dingbian area, Ordos Basin," Journal of Northwest University (Natural Science Edition), vol. 40, no. 2, pp. 293-298, 2010.

[35] X. Y. Shao, J. C. Tian, and Y. J. Fan, "Characteristics and accumulation pattern of oil reservoirs in the $8^{\text {th }}$ member of the Yangchang Formation in Mafang area, Ordos Basin," Oil \& Gas Geology, vol. 36, no. 2, pp. 203-208, 2015.

[36] J. X. Zhao, M. Zou, and Y. Q. Hu, "Fault characteristics of Chang8 oil formation and their impact on reservoir in northwest of Jiyuan, Ordos Basin, China," Journal of Chengdu University Technology (Science \& Technology Edition), vol. 41, no. 3, pp. 257-265, 2014.
[37] S. H. Du, "Characteristics and the formation mechanism of the heterogeneous microfractures in the tight oil reservoir of Ordos Basin,China," Journal of Petroleum Science and Engineering, vol. 191, Article ID 107176, 2020.

[38] X. Z. Shao, M. M. Wang, X. Hui, S. Wang, X. Zhang, and Y. Qi, "Characteristics, formation stages and development model of fractures in Yanchi area, Ordos Basin," Natural Gas Geoscience, vol. 32, no. 10, pp. 1501-1513, 2021.

[39] G. L. Liu, S. Ma, and X. Z. Shao, "Origin of tight reservoir in Chang 8 reservoir in the north of Tianhuan depression, Ordos basin," Journal of Northeast Petroleum University, vol. 40, no. 5, pp. 38-45, 2016.

[40] X. Qiu, C. Liu, G. Mao, Y. Deng, F. Wang, and J. Wang, "Major, trace and platinum-group element geochemistry of the upper triassic nonmarine hot shales in the Ordos basin, Central China," Applied Geochemistry, vol. 53, pp. 42-52, 2015.

[41] Y. Wang, X. C. Chang, Y. Z. Sun, B. Shi, and S. Qin, "Investigation of fluid inclusion and oil geochemistry to delineate the charging history of upper riassic Chang 6, Chang 8 , and Chang 9 tight oil reservoirs, Southeastern Ordos Basin, China," Marine and Petroleum Geology, vol. 113, Article ID 104115, 2020.

[42] Y. Zhou, Y. Ji, L. Xu et al., "Controls on reservoir heterogeneity of tight sand oil reservoirs in upper triassic Yanchang formation in Longdong area, southwest Ordos Basin, China: implications for reservoir quality prediction and oil accumulation," Marine and Petroleum Geology, vol. 78, pp. 110-135, 2016. 